\title{
Pelatihan Sistem Informasi Pelayanan Surat Pengantar Untuk Perangkat Desa Mangunjaya Kecamatan Tambun Selatan Kabupaten Bekasi
}

\author{
Mayadi ${ }^{1}$, Prio Kustanto ${ }^{1, *}$ \\ ${ }^{1}$ Fakultas IImu Komputer; Universitas Bhayangkara Jakarta Raya; Jl. Perjuangan 081, Marga \\ Mulya, Bekasi Utara; Telp. 02188955882/ +622188955871; e-mail: \\ mayadi@dsn.ubharajaya.ac.id, pkustanto@dsn.ubharajaya.ac.id \\ * Korespondensi: e-mail: pkustanto@dsn.ubharajaya.ac.id
}

Submitted: 28/12/2021; Revised: 04/01/2022; Accepted: 12/01/2022; Published: 31/01/2022

\begin{abstract}
Utilization of information and communication technology is applied to help facilitate human work and make it easier to get information. Utilization of information technology for government agencies is a useful tool to improve services to the community. Mangunjaya Village is a government agency at the village level that directly provides services to the community. The services provided include making cover letters, such as Identity Cards (KTP), Family Cards (KK) and Birth Certificates. With the help of information system technology, the Cover Letter service for the Mangunjaya Village Apparatus, Tambun Selatan District, is expected to help the community service so that it can be relatively more optimal and faster. This activity, which was held in Mangunjaya Village, out of a total of 30 participants who expressed satisfaction with the seminar held in Mangunjaya Village, as many as 57\% were very satisfied, $30 \%$ satisfied and $13 \%$ said they were quite satisfied with the presentation delivered by the speaker.
\end{abstract}

Keywords: Information, Information System, Letter, Service, System

\begin{abstract}
Abstrak
Pemanfaatan teknologi informasi dan komunikasi diterapkan untuk membantu memudahkan pekerjaan manusia dan mempermudah mendapatkan informasi. Pemanfaatan teknologi informasi bagi instansi pemerintah merupakan alat bantu yang berguna untuk meningkatkan pelayanan kepada masyarakat. Desa Mangunjaya merupakan instansi pemerintah pada tingkat desa yang langsung melakukan pelayanan kepada masyarakat. Pelayanan yang diberikan diantaranya adalah pembuatan surat pengantar, seperti Kartu Tanda Penduduk (KTP), Kartu Keluarga (KK) dan Akta Kelahiran. Dengan bantuan teknologi sistem Informasi pelayanan Surat Pengantar untuk Perangkat Desa Mangunjaya Kecamatan Tambun Selatan diharapkan dapat membantu pelayanan masyarakat hingga dapat relatif lebih optimal dan cepat. Kegiatan yang diselenggarakan di Desa Mangunjaya ini dari total 30 peserta yang menyatakan kepuasan terhadap seminar yang dilakukan di Desa Mangunjaya, sebanyak $57 \%$ sangat puas, $30 \%$ puas dan $13 \%$ menyatakan cukup puas dengan pemaparan yang disampaikan oleh pembicara.
\end{abstract}

Kata kunci: Informasi, Sistem Informasi, Pelayanan, Surat, Sistem

\section{Pendahuluan}

Pemanfaatan teknologi informasi dan komunikasi diterapkan untuk membantu memudahkan pekerjaan manusia dan mempermudah mendapatkan informasi. Pemanfaatan teknologi informasi bagi instansi pemerintah merupakan alat bantu yang berguna untuk meningkatkan pelayanan kepada masyarakat. Menyikapi era teknologi basis 4.0 saat ini, 
keberadaan situs web atau website telah secara luas dimanfaatkan sebagai media promosi dan pemasaran produk lokal, media penyebaran informasi dan edukasi masyarakat, maupun sebagai media untuk menyampaikan laporan, usulan serta kritik (Wiratmo et al., 2017)

Desa Mangunjaya merupakan instansi pemerintah pada tingkat desa yang langsung melakukan pelayanan kepada masyarakat. Pelayanan yang diberikan diantaranya adalah pembuatan surat pengantar, seperti Kartu Tanda Penduduk (KTP), Kartu Keluarga (KK) dan Akta Kelahiran. Pada prosesnya biasanya terjadi antrian di kelurahan Mangunjaya pada loket administrasi. (Prio Pamungkas et al., 2021) Jika berkas persyaratan lengkap akan ditumpuk pada meja administrasi dan masyarakat menunggu sehingga tidak ada kepastian selesainya surat pengantar tersebut karena tidak adanya nomor urut antrian berkas yang akan di proses. Sedangkan jika persyaratan berkas ada yang belum lengkap masyarakat akan pulang untuk melengkapinya. Hal ini akan memakan waktu yang cukup lama. Berdasar kondisi tersebut, maka keterlibatan sistem diperlukan untuk membantu kinerja dan kualitas pelayanan yang lebih optimal dan efisien. Dalam hal tata kelola pemerintahan, situs web memiliki fungsi strategis sebagai perangkat yang mendukung jalannya aktivitas pemerintahan dimana keberadaannya berperan dalam hubungan dengan masyarakat secara digital (Cahyana \& Zakariya, 2017)

Salah satu cara untuk memudahkan masyarakat yang akan membuat surat pengantar KTP, KK dan Akta Kelahiran adalah dengan menggunakan sistem informasi pelayanan online. Masyarakat yang ingin membuat surat pengantar bisa dilakukan dimana saja dengan adanya jaringan internet. (Prio Pamungkas et al., 2021)

Pencatatan dan pengolahan data penduduk merupakana tanggung jawab pemerintah kabupaten/kota, dimana pelaksanaanya diawali dari kelurahan selaku ujung tombak pendaftaran penduduk. Pelayanan tersebut perlu dilakukan dengan cepat dan tepat untuk mendapatkan suatu informasi. Tetapi pada kenyataannya, pengolahan data pada kelurahan atau desa masih dilakukan dalam bentuk pembukuan atau arsip - arsip, sehingga seringkali terjadi kesalahan bahkan ada arsip data yang hilang atau rusak karena terlalu banyaknya arsip yang ada. Pada aktifitas pelayanan kependudukan, warga diharuskan mengurus surat surat permohonan yang diinginkan pada kantor desa/kelurahan dengan mengikuti sejumlah prosedur prosedur yang berlaku sehingga dalam pembuatan surat surat tertentu akan memakan waktu dan tenaga yang cukup lama. (Faqih, 2019)

Pelayanan publik seperti pengurusan dokumen Surat Keterangan atau SK seperti contoh pengurusan SK-Kematian, SK-Kelahiran, SK-KTP, Proses dan lainnya masih menggunakan cara konvensional. Cara konvensional yang dimaksud adalah dalam pengurusan dokumen surat keterangan tahapan yang harus dilalui adalah dengan menuliskan identitas yang mengajukan surat keterangan ke dalam buku registrasi. Selanjutnya, nomor dari buku registrasi digunakan untuk nomor surat. Setelah itu, identitas lainnya beserta nomor surat dimasukkan kedalam draf surat keterangan. (Winarna et al., 2018)

Surat menyurat merupakan suatu aktifitas antara satu pihak dengan pihak yang lain untuk mengadakan hubungan secara terus menerus. Pada umumnya kegiatanya 
suratmenyurat dilakukan secara manual dengan menggunakan metode pengiriman via pos. Namun seiring perkembangan teknologi, kegiatan surat-menyurat kini bisa dilakukan dengan lebih cepat dan aman menggunakan bantuan teknologi baik menggunakan e-mail, aplikasi sosial media maupun aplikasi-aplikasi terkait lainnya. (Junus, 2018)

Banyak kegiatan yang dilakukan hanya dalam lingkup terbatas kini dapat dilakukan dalam cakupan yang sangat luas, bahkan mendunia. Keberadaan pengolahan data menjadi informasi secara terkomputerisasi menjadi sangat penting. Hal itu dikarenakan pengolahan data secara terkomputerisasi dapat memberikan kontribusi yang besar untuk kinerja suatu organisasi. Jika dibandingkan pengolahan data secara manual, pengolahan data secara terkomputerisasi memiliki banyak keunggulan, seperti pengolahan data yang cepat dan akurat. (Santosa, 2014)

Pelatihan ini juga untuk meningkatkan keterampilan ini, pada tahap awal dapat dilakukan secara gratis dulu untuk meningkatkan minat dan motivasi belajar bagi perangkat desa. Dengan diberikan pelatihan secara gratis ini adalah untuk menumbuhkan kesadaran mengenai pentingnya teknologi dan menciptakan minta serta motivasi dalam melakukan perubahan. Disisi lain terdapat faktor penghambat dalam pelatihan ini seperti kurangnya sarana dan prasarana dalam pelaksanaan pelatihan gratis ini dan masih adanya sikap yang tradisional terhadap pelatihan ini (Dewi, 2016).

Program Pengabdian kepada Masyarakat ini bertujuan untuk memberikan Wawasan tambahan terkait perkembangan teknologi informasi dalam pemanfaatannya di berbagai bidang termasuk pelayanan masyarakat; dan memberikan bekal tambahan kepada peserta dalam hal melaksanakan tugas pelayanan masyarakat.

\section{Metode Pelaksanaan}

Metode pelaksanaan Pengabdian kepada Masyarakat di Desa Mangunjaya dengan tema "Pelatihan Sistem Informasi Pelayanan Surat Pengantar untuk Staf Perangkat Desa Mangunjaya Kecamatan Tambun Selatan. Acara yang dilakukan menyesuaikan dengan kondisi sekarang. Kegiatan dilaksanakan secara tata muka langsung (luring) dan tetap menjaga dan melaksanakan protokol kesehatan terkait dengan COVID 19.

Ada enam tahapan yang dilakukan, yaitu 1.) Persiapan 2.) Penyampaian materi 3.) Diskusi bersama 4.) Membuat kesimpulan dan saran 5.) Pemberian Cendramata 6.) Pengisian Kuisioner.

Persiapan awal sebelum rangkaian pelatihan dimulai, dilakukan penyambutan narasumber atau pembicara kepada peserta yang dilakukan oleh kepala desa.

Penyampaian materi mengenai materi perkembangan teknologi informasi dilanjutkan dengan materi pemanfaatan sistem informasi disela dengan diskusi secara sekaligus sehingga berjalan lebih dinamis serta memberi kesimpulan dan saran kepada peserta untuk kedepannya.

Diakhiri dengan pemberian cinderamata dan plakat dari tim dosen Informatika Fasilkom Ubhara Jaya kepada kepala desa Mangunjaya serta pengisian kuisioner untuk para peserta 
yang hadir. pada tahapan pengisian kuesioner dilakukan oleh peserta yang sudah disiapkan secara online dalam Google Form (Gubuk Pintar, 2020). Hasil jawaban peserta dijadikan data bahasan untuk mengevaluasi bagaimana progress pemahaman dan kesan peserta setelah mengikuti pelatihan.

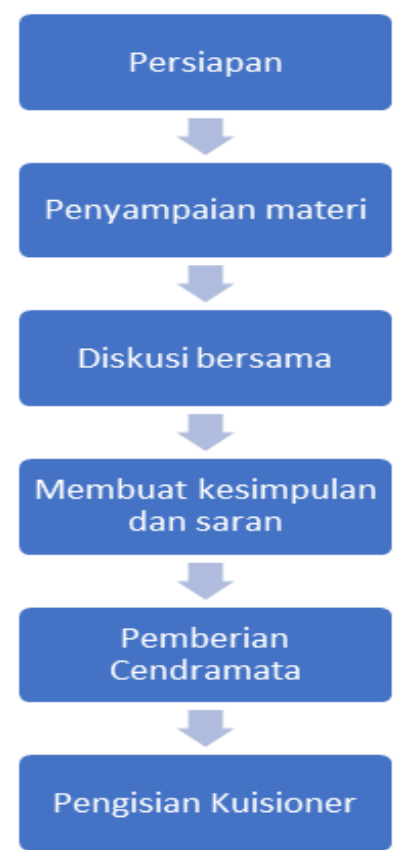

Sumber: Hasil Pelaksanaan (2021)

Gambar 1. Urutan Kegiatan Abdimas

\section{Hasil dan Pembahasan}

\subsection{Hasil Perancangan Sistem}

Kegiatan ini menampilkan bentuk sistem informasi pelayanan surat menyurat untuk dipaparkan kepada peserta yang hadir langsung di Desa Mangunjaya, Tambun Selatan, Kabupaten Bekasi. Pada Hari Jumat, 03 September 2021. Gambar 2 menampilkan halaman utama dari sistem informasi yang dijelaskan ketika pelatihan berlangsung.

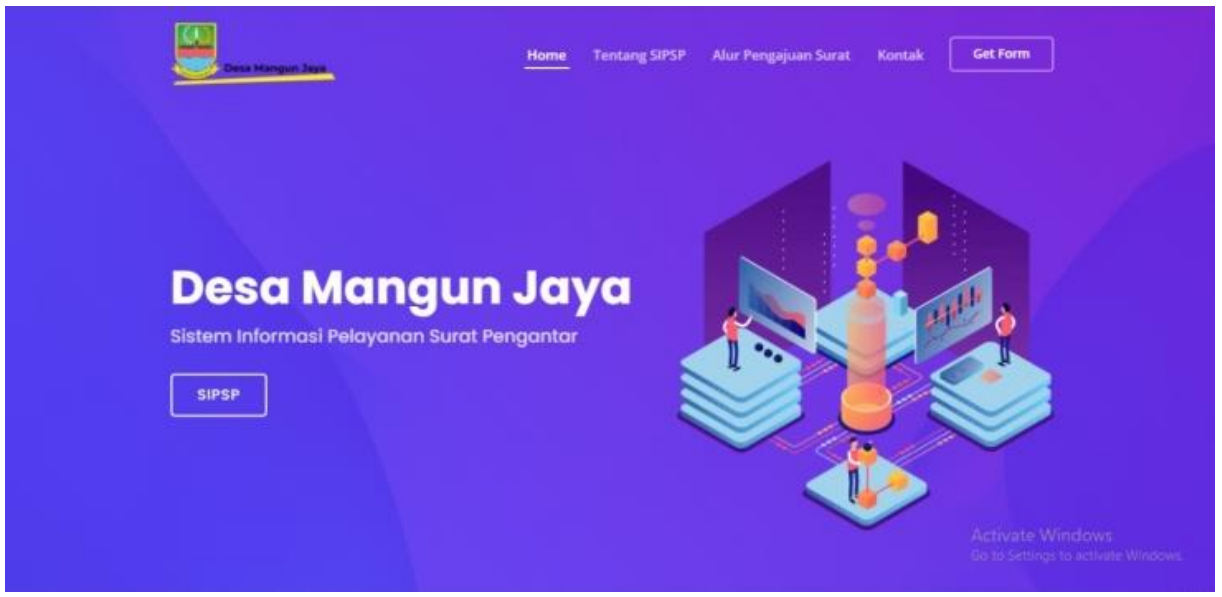

Sumber: Hasil Pelaksanaan (2021)

Gambar 2. Halaman Utama 
Gambar 3. menampilkan halaman pengenalan sistem yang menggambarkan kegunaan ataupun fungsi dari sistem informasi yang dijelaskan ketika pelatihan berlangsung.

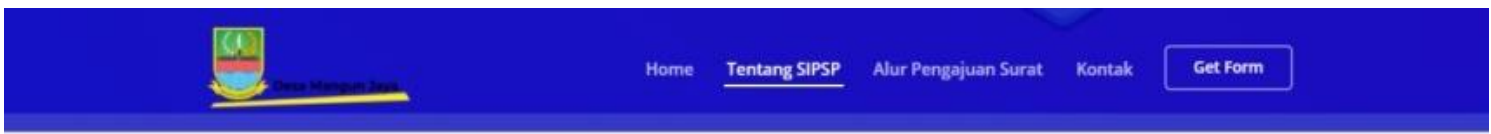

\section{Tentang SIPSP}

SIPSP yoitu Sistem informosi Peloyanan Surat Pengantar yong dapot memberikan pelayanan bagi masyarakat di Desa Mangun jaya dalam pengajuan pembuatan surat pengantor seperti:

() Surat Pengantar KTP

(1) Surat Pengantar KK

(-) Surat Pengantar Akte Kelahiran

(1) Surat Keterangan Pindah

(1) Surat Izin Berpergian

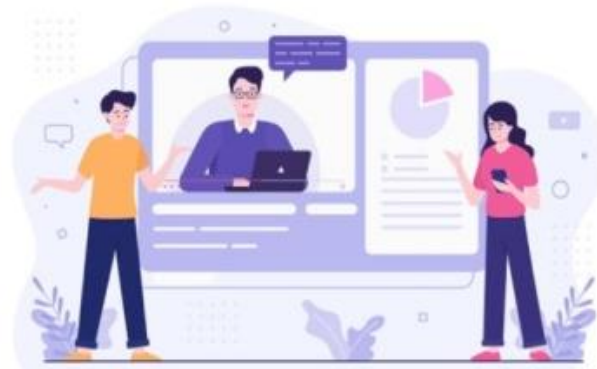

Sumber: Hasil Pelaksanaan (2021)

Gambar 3. Pengenalan Sistem

Gambar 4. menampilkan alur pengajuan surat dari sistem informasi yang dijelaskan ketika pelatihan berlangsung.

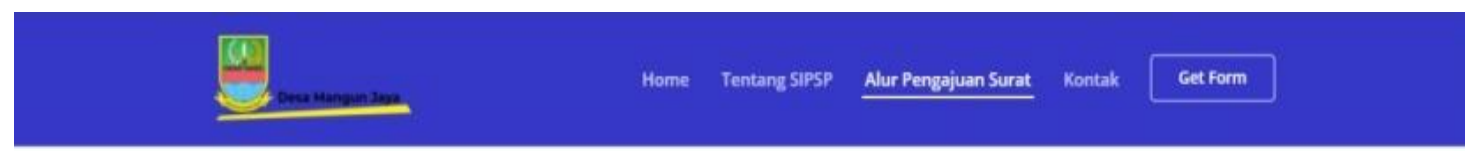

\section{ALUR PENGAJUAN SURAT}

Dimohon untuk membaca dengan teliti dan cermat.
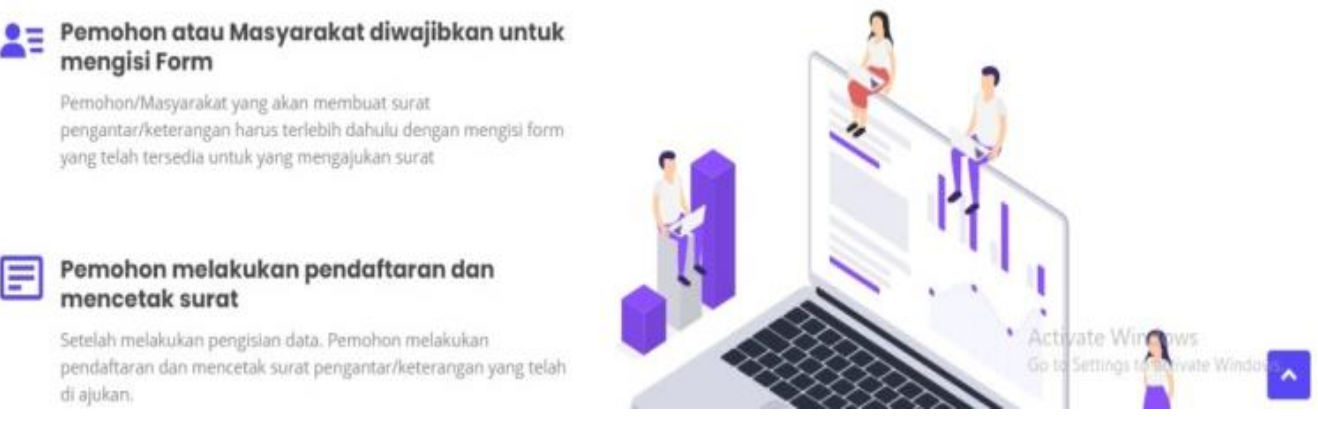

Sumber: Hasil Pelaksanaan (2021)

Gambar 4. Alur Pengajuan Surat

Gambar 5. menampilkan pilihan menu pembuatan yang ada pada sistem informasi dan dijelaskan ketika pelatihan berlangsung. 


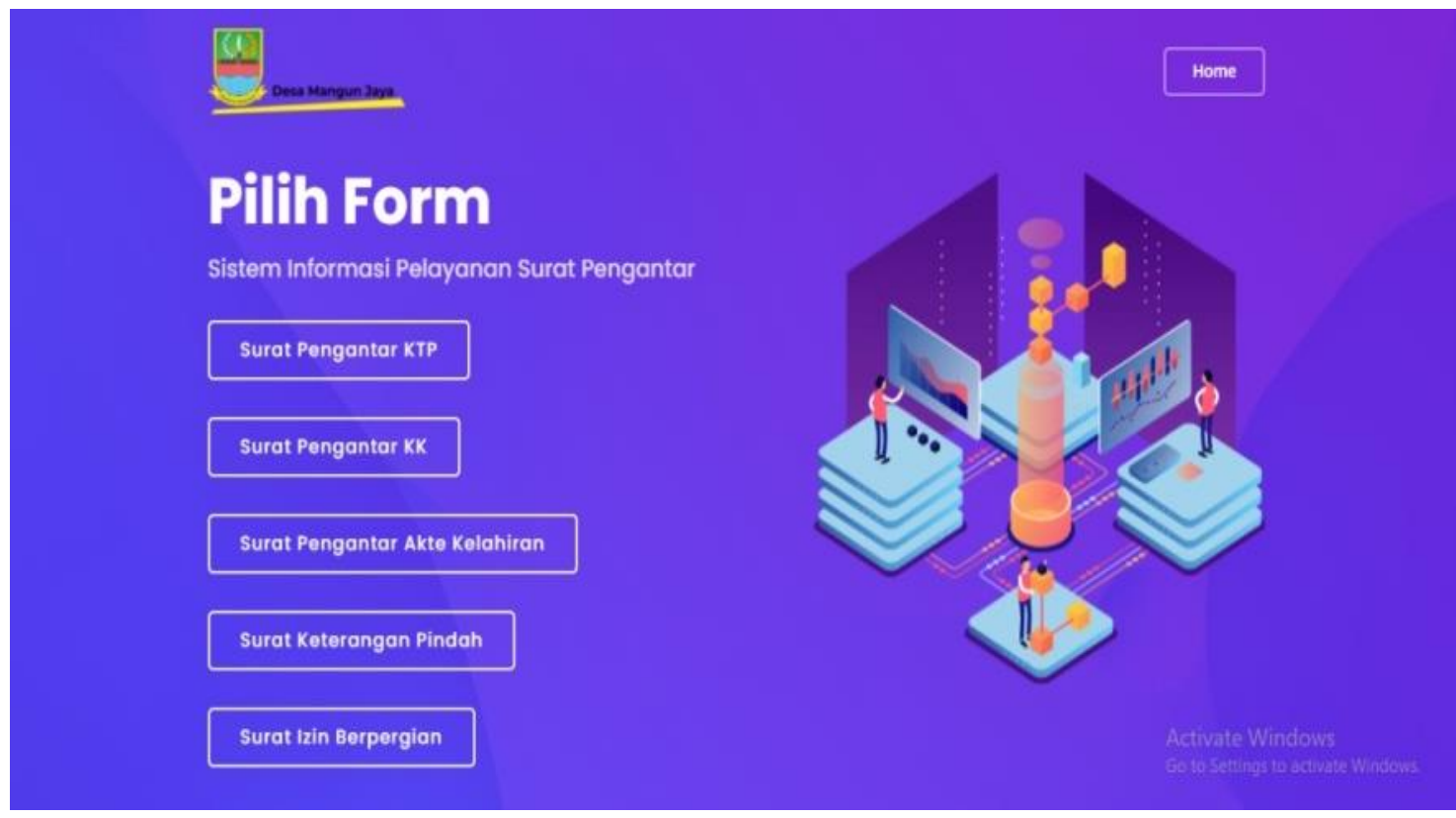

Sumber: Hasil Pelaksanaan (2021)

Gambar 5. Pemilihan Form Pengajuan Surat

Gambar 6 menampilkan hasil pengajuan surat pengantar. Tampilan ini merupakan proses akhir dari sistem informasi dan dijelaskan ketika pelatihan berlangsung. Sistem Informasi ini terintegrasi dirancang untuk mempermudah pengguna dalam hal ini masyarakat dan staf kantor dalam pelaksanaan aktifitas pengajuan surat permohonan. Sistem ini dirancang dengan berbasis website dan android dengan desain yang user-friendly (Prasetyo et al., 2016).

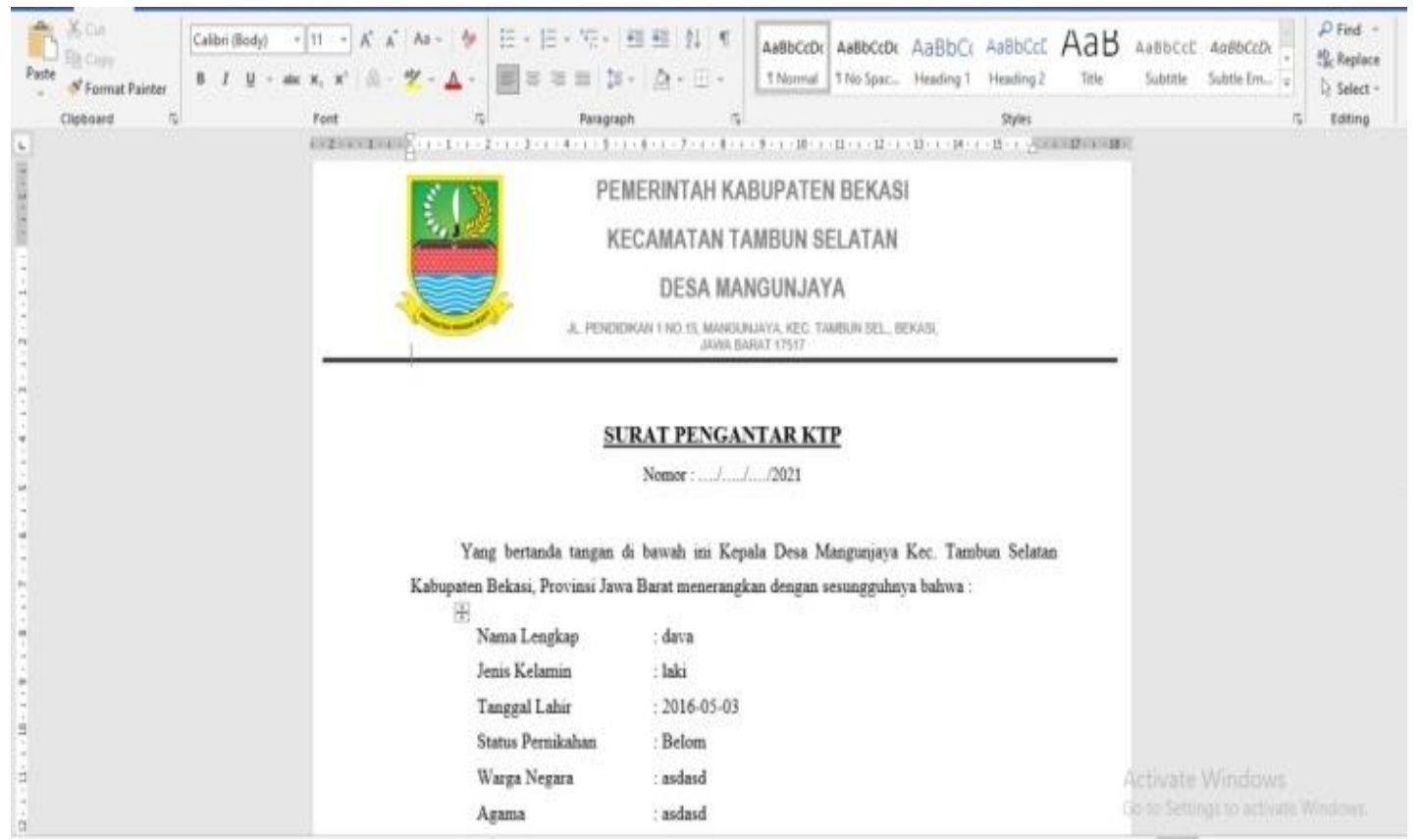

Sumber: Hasil Pelaksanaan (2021)

Gambar 6. Pemilihan Form Pengajuan Surat 


\subsection{Luaran Kegiatan}

Target luaran yang akan dihasilkan adalah a) Membuka pengetahuan dan wawasan ilmu dan pengetahuan tentang bagaimana memanfaatkan dan menggunakan teknologi informasi yang bermanfaat. Hal ini dapat diaplikasikan oleh peserta untuk meningkatkan ilmu pengetahuan. Hasil yang di dapat dari para peserta diantaranya berupa lebih selektif lagi dalam mengelola data setelah mengikuti seminar; b) Menerapkan dan menyebarluaskan hasil-hasil pengabdian masyarakat dalam bentuk jurnal di Jurnal LPPM, di mnctrijaya.com dan Beritalima.com serta modul pelatihan kepada masyarakat sebagai bagian dari upaya untuk memberdayakan dan meningkatkan kualitas hidup masyarakat; Para peserta nantinya juga mendapatkan e-sertifikat setelah selesai pengabdian masyarakat.

\subsection{Hasil Kegiatan Menurut Peserta}

Hasil kuisioner sebelum pelatihan, Gambar 7. Menampilkan hasil grafik tentang pemahaman peserta terhadap teknologi informasi.

\section{PEMAHAMAN PERANGKAT DESA DALAM PELAYANAN MASYARAKAT MENGGUNAKAN TEKNOLOGI INFORMASI}

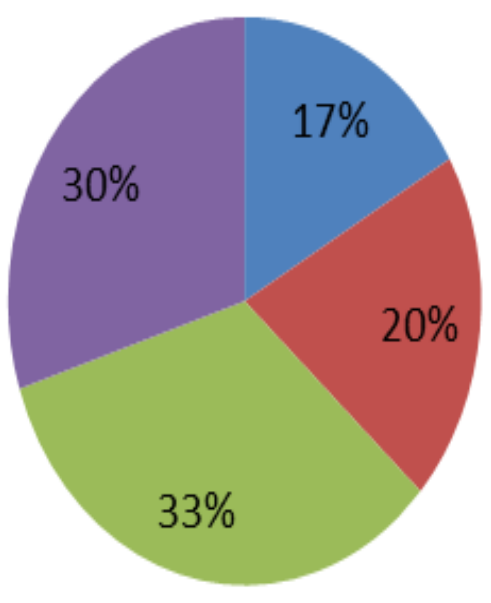

- Sangat Baik

Baik

- Cukup

- Kurang Baik

Sumber: Hasil Pelaksanaan (2021)

Gambar 7. Pemahaman Tentang Teknologi Informasi Sebelum pelatihan

Dari gambar 7 diperoleh hasil dari total 30 peserta yang mengikuti pelatihan yang dilakukan di Desa Mangunjaya, sebanyak 30\% kurang baik dalam pemahaman teknologi informasi, $33 \%$ cukup dan $20 \%$ menyatakan baik dan $17 \%$ sangat baik dalam memahami teknologi informasi.

Hasil kuisioner sesudah pelatihan untuk mengetahui pemahaman perangkat desa dalam pelayanan masyarakat menggunakan teknologi informasi ditunjukkan pada gambar 8 . 


\section{PEMAHAMAN PERANGKAT DESA DALAM PELAYANAN MASYARAKAT MENGGUNAKAN TEKNOLOGI INFORMASI}

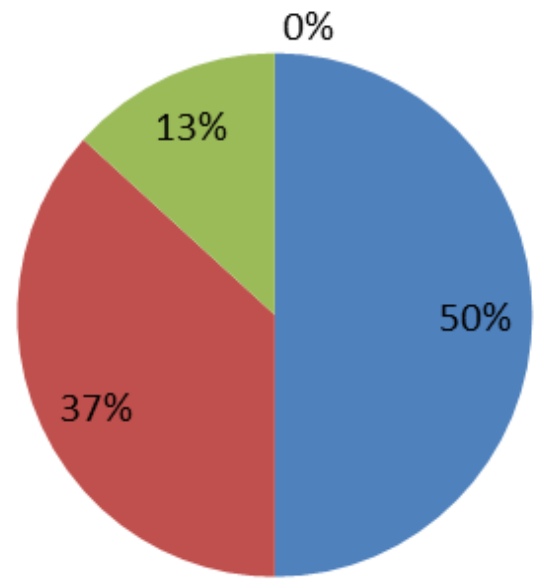

- Sangat Baik

Baik

Cukup

Kurang Baik

Sumber: Hasil Pelaksanaan (2021)

Gambar 8. Pemahaman Tentang Teknologi Informasi Sesudah pelatihan

Hasil grafik setelah mengikuti pelatihan, sebanyak $13 \%$ peserta cukup mengerti tentang teknologi informasi, $37 \%$ perserta baik dan $50 \%$ menyatakan sangat baik dalam memahami teknologi informasi.

Hasil kuisioner peranan teknologi dalam pembuatan surat pengantar ditunjukkan pada gambar 9 .

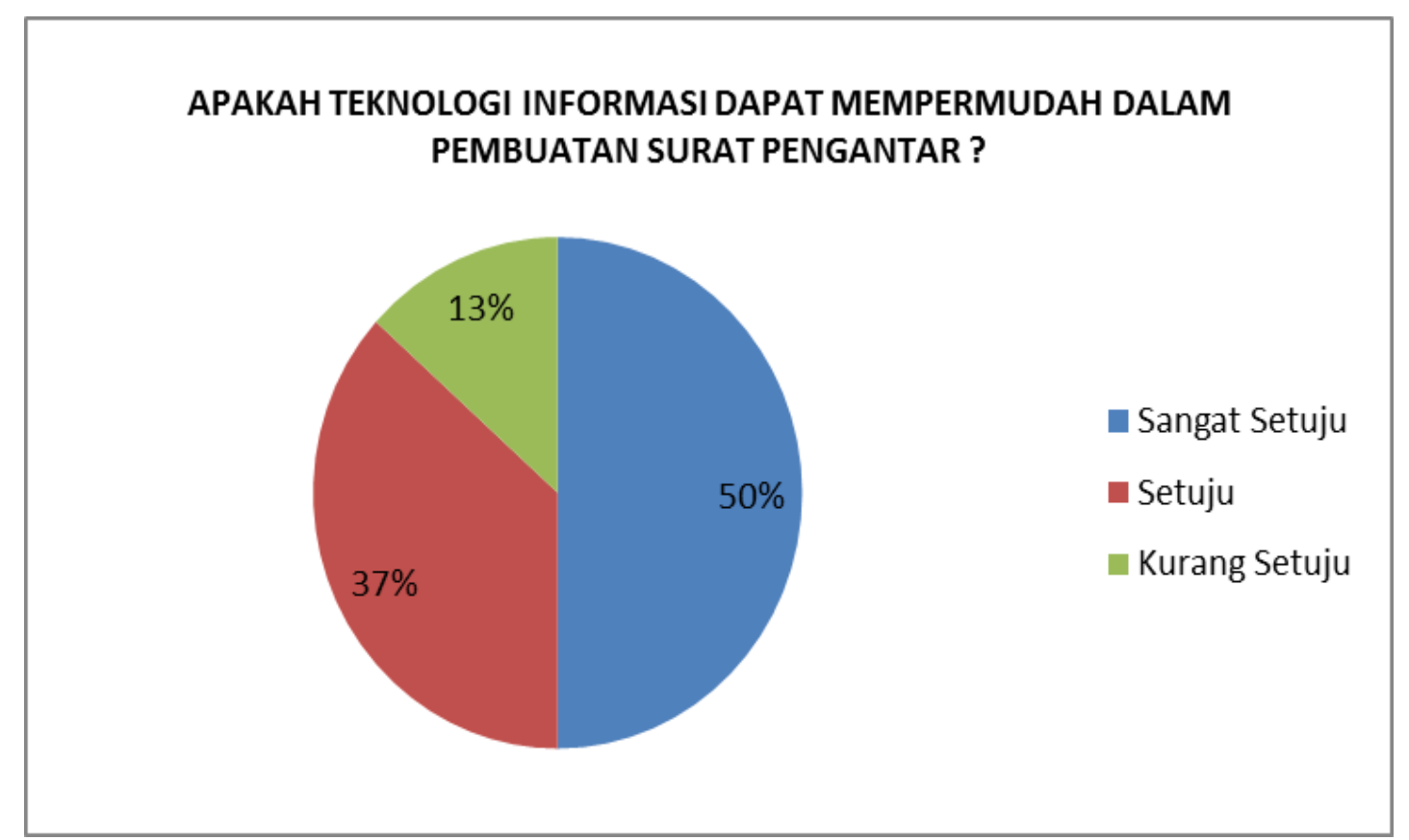

Sumber: Hasil Pelaksanaan (2021)

Gambar 9. Peranan Teknologi Informasi 
Berdasarkan hasil yang ditampilkan menunjukkan grafik kuisioner kepada peserta mengenai teknologi informasi dan terdapat, sebanyak $13 \%$ peserta kurang setuju, $37 \%$ Setuju dan $50 \%$ menyatakan sangat setuju peranan teknologi informasi dapat mempermuadah dalam pembuatan surat pengantar.

Hasil kuisioner mengenai pemahaman peserta terhadap materi yang dipaparkan oleh narasumber ditunjukkan pada gambar 10 .

\section{APAKAH MATERI YANG DISAMPAIKAN NARASUMBER MUDAH UNTUK DIMENGERTI ?}

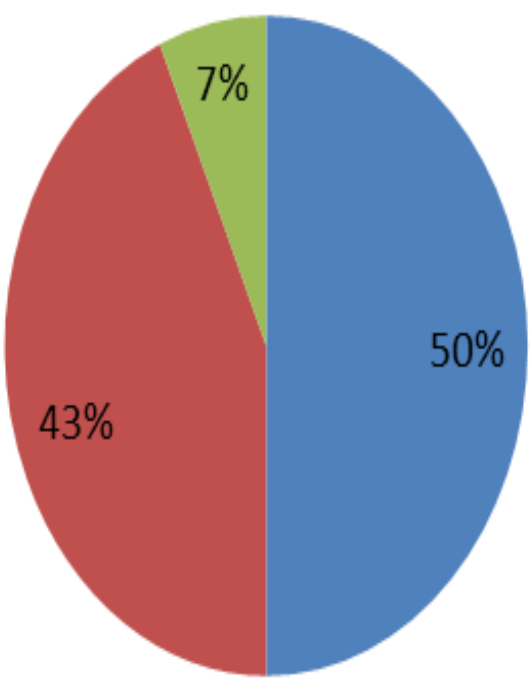

Sangat Jelas

Jelas

Kurang

Sumber: Hasil Pelaksanaan (2021)

Gambar 10. Penyampaian Materi Narasumber

Berdasarkan grafik kuisioner kepada peserta mengenai penjelasan informasi dari narasumber dan terdapat, sebanyak $7 \%$ peserta kurang, $43 \%$ Jelas dan $50 \%$ menyatakan sangat Jelas dengan penyampaian materi yang diberikan.

Gambar 11. Menampilkan grafik kepuasan peserta yang hadir atas kegiatan yang diselenggarakan di Desa Mangunjaya dan dari total 30 peserta yang menyatakan kepuasan terhadap seminar yang dilakukan di Desa Mangunjaya, sebanyak $57 \%$ sangat puas, $30 \%$ puas dan $13 \%$ menyatakan cukup puas dengan pemaparan yang disampaikan oleh pembicara. 


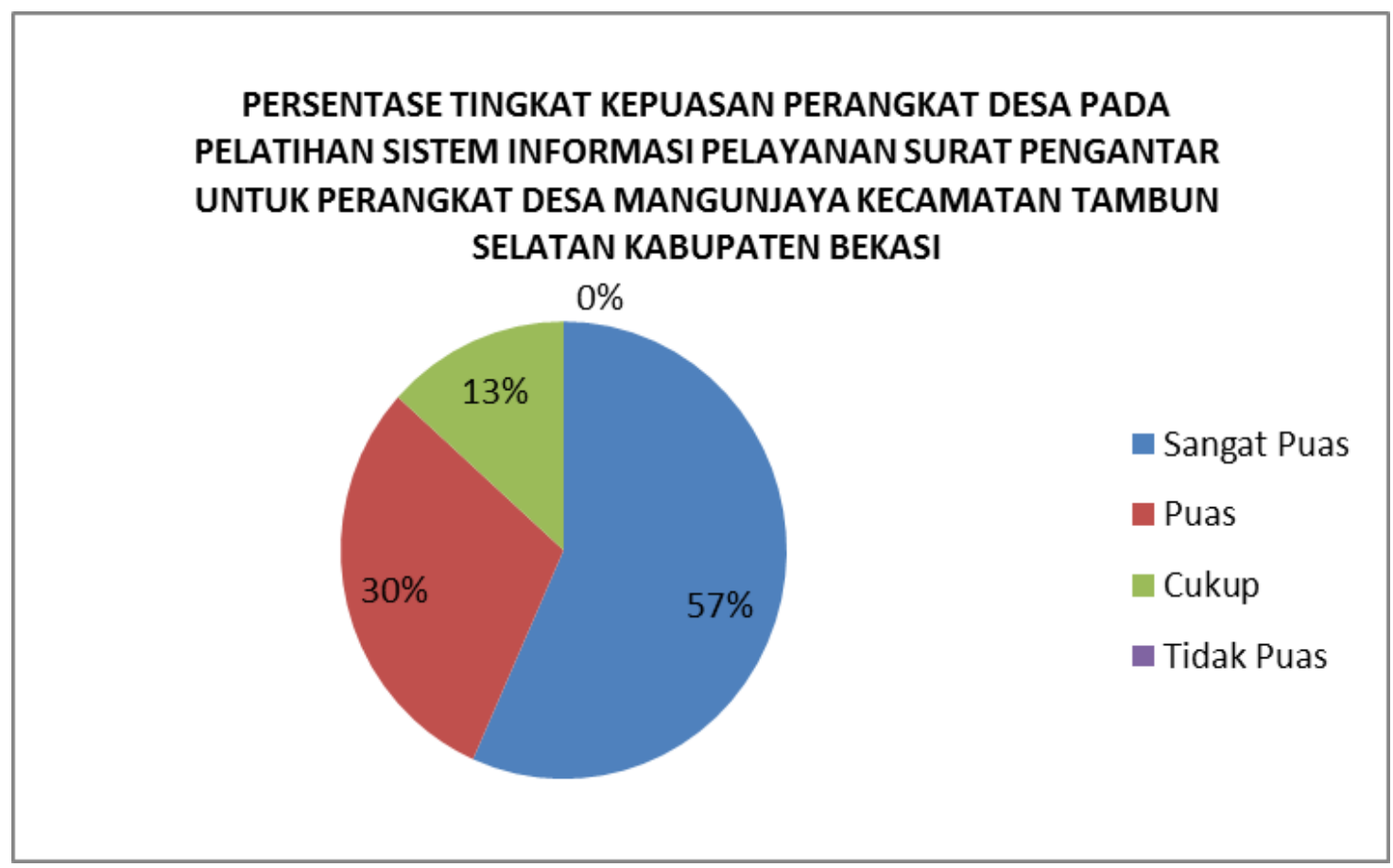

Sumber: Hasil Pelaksanaan (2021)

Gambar 11. Persentase Tingkat Kepuasan

Gambar 12. Menampilkan jabatan para peserta yang menghadiri kegiatan dan Dari total 30 peserta, 2 di antaranya kepala dusun, 2 kepala saksi, 4 kepala urusan, dan terdapat 22 staff yang mengikuti.

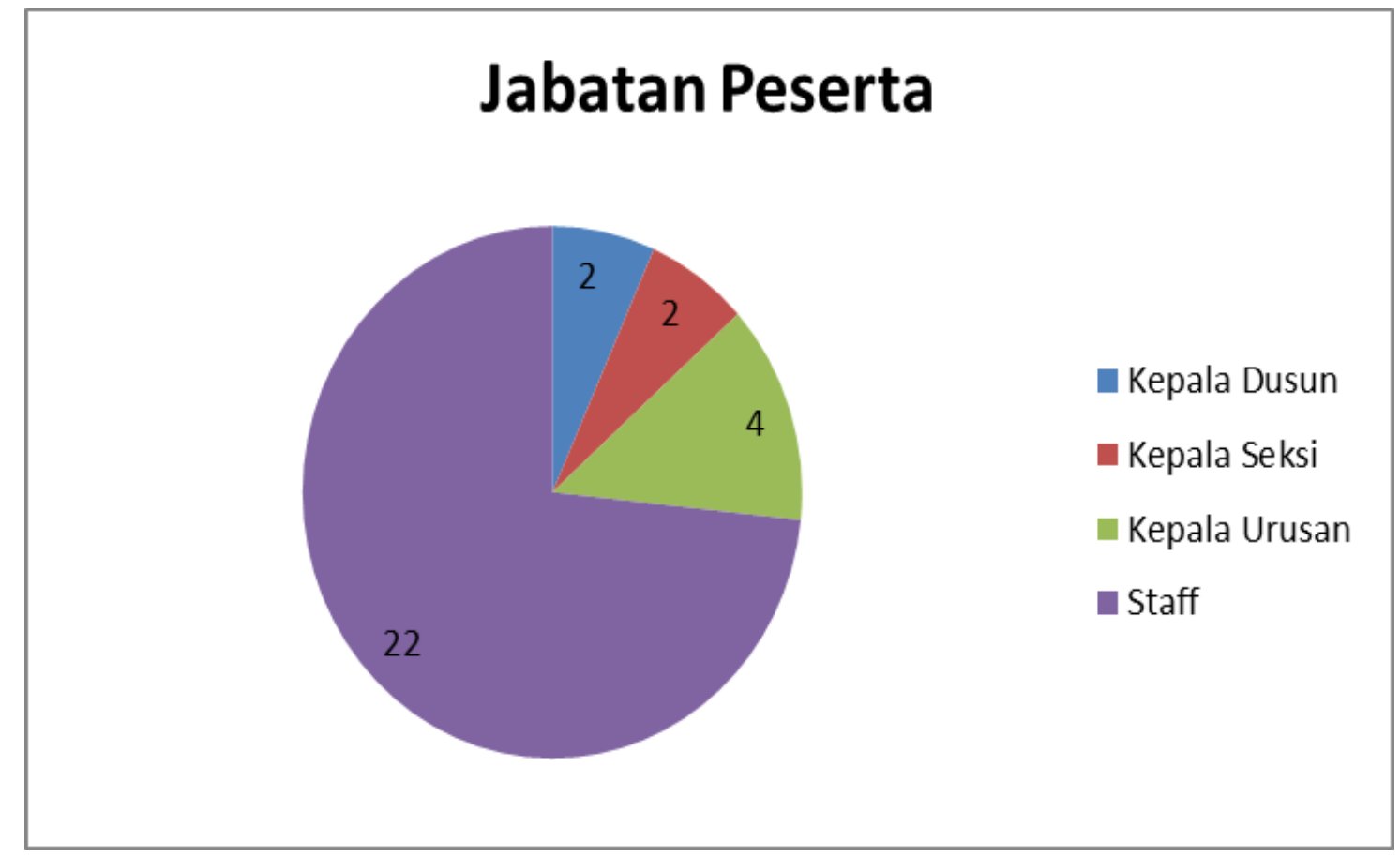

Sumber: Hasil Pelaksanaan (2021)

Gambar 12. Jabatan Peserta 
Pada Gambar 13. menampilkan dokumentasi kegiatan dari persiapan hingga pemberian cinderamata yang berlangsung secara tatap muka langsung (luring).

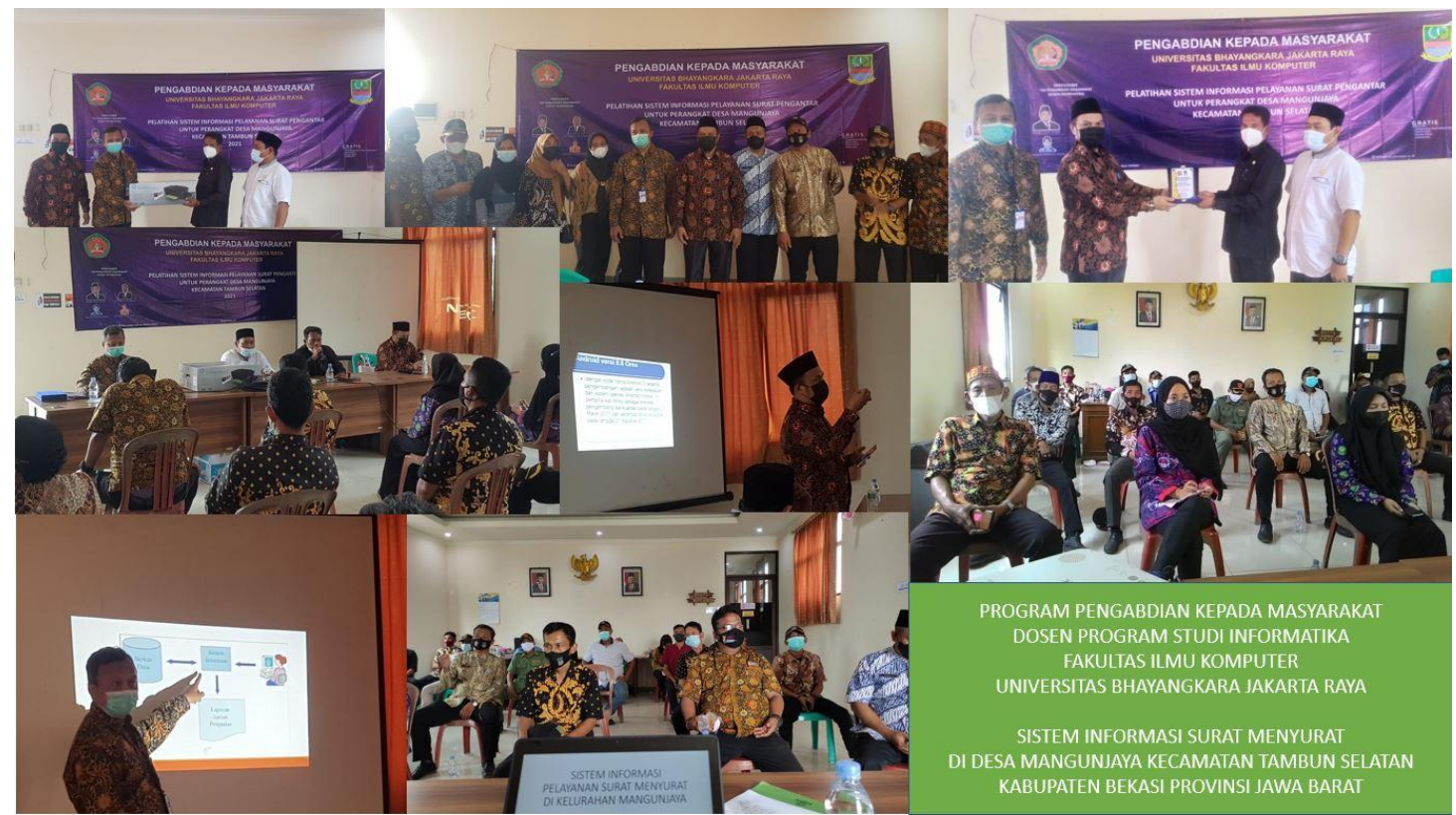

Sumber: Hasil Pelaksanaan (2021)

Gambar 13. Hasil Kegiatan

\section{Kesimpulan}

Kegiatan Pengabdian masyarakat yang dilakukan di Desa Mangunjaya disambut baik oleh perangkat desa setempat dan dirasakan bermanfat untuk menambah pengetahuan dan wawasan terkait perkembangan teknologi terkini dan pemanfaatannya pada proses pekerjaan keseharian. Pelaksanaan Program Pengabdian Masyarakat perlu dilanjutkan untuk memberikan kontribusi dosen sebagai insan akademik dan peneliti kepada masyarakat.

\section{Ucapan Terimakasih}

Terima kasih kepada Universitas Bhayangkara Jakarta Raya dan pihak Mitra yaitu Desa Mangunjaya yang telah memberikan dukungan, kesempatan dan meluangkan waktu dalam pelaksanaan kegiatan Pelatihan Sistem Informasi Pelayanan Surat Pengantar Untuk Perangkat Desa Mangunjaya Kecamatan Tambun Selatan Kabupaten Bekasi.

\section{Daftar Pustaka}

Cahyana, R., \& Zakariya, M. I. (2017). Pengembangan Papan Informasi Digital Untuk Menyiarkan Ulang Informasi Yang Diterbitkan Pada Situs Web. Jurnal Algoritma. https://doi.org/10.33364/algoritma/v.13-2.281

Dewi, A. C. (2016). Pelatihan Komputer Gratis di Kampoeng Pintar Sebagai Pemberdayaan Masyarakat (Studi Kasus di Desa Suwawal Timur, Pakis Aji Kabupaten Jepara). http://lib.unnes.ac.id/28481/1/1201412040.pdf 
Faqih, M. (2019). Sistem Informasi Pelayanan Surat-Menyurat Berbasis Web Di Desa Palang Kecamatan Palang Kabupaten Tuban. Repository.Unim.Ac.Id.

Gubuk Pintar. (2020). Cara Membuat Google Form untuk Kuisioner Survey. Gubukpintar.Com. https://www.gubukpintar.com/2018/06/cara-membuat-google-form.html

Junus, M. (2018). Sistem Informasi Pengelolaan Surat Masuk \& Surat Keluar Jurusan Teknik Elektro Politeknik Negeri Malang Berbasis Web Melalui Jaringan Intranet Polinema. Jurnal Eltek. https://doi.org/10.33795/eltek.v16i2.97

Prasetyo, N. D., Supratman, D., Fauzi, W. A. H., \& Murti, S. (2016). Perancangan Sistem Informasi E-Farming Berbasis Web untuk Mengetahui Tingkat Kelayakan Panen pada Sektor Pertanian. Seminar Nasional Aplikasi Teknologi Informasi.

Prio Pamungkas, R. W., Fathurrozi, A., Kustanto, P., \& Achmad H., A. (2021). Pelatihan Pembuatan Toko Online Untuk Staf dan Akademisi Ubhara Jaya. Journal Of Computer Science Contributions (JUCOSCO). https://doi.org/10.31599/jucosco.v111.489

Santosa, A. T. D. (2014). Sistem Informasi Administrasi Surat Masuk Dan Surat Keluar Pada Badan Kepegawaian Daerah Kota Semarang. Universitas Dian Nuswantoro Semarang.

Winarna, T. R., Aknuranda, I., \& Saputra, M. C. (2018). Pengembangan Sistem Informasi Pelayanan Surat Keterangan Studi Kasus: Pemerintah Desa Legundi Kecamatan Karangjati Kabupaten Ngawi. Jurnal Pengembangan Teknologi Informasi Dan IImu Komputer.

Wiratmo, B. L., Irfan, N., \& Kuwatono. (2017). Website Pemerintah Daerah Sebagai Sarana Online Public Relations. Jurnal ASPIKOM. 